\title{
The Concept of Power in Norman Mailer's The Naked and the Dead: A Study in Psychological and Sociopolitical Perspectives
}

\author{
${ }^{(1)}$ Instr. Mushtaq Abdulhaleem Mohammed \\ Al-Iraqi University College of Arts Department of English
}

\author{
${ }^{(2)}$ Instr. Khalid Qais Abd \\ University of Anbar - College of Education for Humanities - Department of English
}

\begin{abstract}
As one of the literary figures in post-war American literature, Norman Mailer tackles psychological and sociopolitical issues in The Naked and the Dead (1948) that bewildered both critics and readers. He combined them in a complementary way that explained their cause and effect development. The present paper sheds light on the definition of power in comparison with megalomania, its different causes, and its devastating effects on both the victimizers and the victimized. It also aims at revealing the inner thought of the contemporary individual as suffering from the spiritual decadence as a rebellion against the political life that hovers almost every aspect of the American society. These points are rendered through Mailer's major and powerful characters like General Cummings and Lieutenant Croft who represent the victimizers as a part of their megalomaniac attitudes. An emphasis has always been directed to two other powerless characters - Lieutenant Hearn and Troop Red Valsen - whom will be victimized at the hands of the victimizers. Mailer, in this novel, calls that the individual is either supposed to surrender to wrongful forces or to endeavor to attain some spiritual independence and dignity.
\end{abstract}

Keywords:

Norman Mailer; The Naked and the Dead; power; megalomania; victimization; Michel Foucault

\section{Introduction}

\subsection{Power: Definitions}

Philosophically, Michel Foucault (1926-1984), a French philosopher, historian of ideas, social theorist, and literary critic, believes that power is a "problem," "exploitation," and "a total enigma." Foucault describes power as "visible and invisible, present and hidden [as well as] ubiquitous." He also adds: "Everywhere that power exists, it is being exercised" (Power/Knowledge, 213). Max Weber (1864-1920), the German sociologist and philosopher, defines power as the possibility that "one actor within a social relationship will be in a position to carry out his own will despite resistance, regardless of the basis on which this probability rests" (qdt. in Swedberg 205). Power has numerous definitions and categories: "the ability to control people or things" and/or "the right or authority of a person or group to do something" (Hornby 1187). Power is practiced in a controlling and dominating way that ignores people's resistance, not to mention the nature of the rapport between the powerful and the powerless. Furthermore, in the opinion of Ashley Crossman, power is

[T] he ability to control others, events, or resources; to make happen what one wants to happen in spite of obstacles, resistance, or opposition. Power is a thing that is held, coveted, seized, taken away, lost, or stolen, and it is used in what are essentially adversarial relationships involving conflict between those with power and those without.

Power relates to psychology for it is an extension to megalomania which technically means "mental illness or condition in which [people have] an 
exaggerated belief in their importance or power." Psychologically, it means a person's "strong feeling which provokes him to have more and more power" (Hornby 957). Thus, the two terms are complementary, not contradictory, and they seem to be as causes and effects to one other.

$$
\text { Mailer's personality comprises }
$$
megalomaniac qualities. He keeps exceeding the limits by using different literary genres to "reshape reality in some small way with "fiction" as a guide" (qdt. in Bailey 1). Mailer's feelings and confidence in his power make him ambitious and broadminded as well as ready to emphasize a new concept of reality through fiction. Throughout The Naked and the Dead, Mailer refers to megalomania and its influence on the man to prove that it leads to violence which is "individually satisfying" to some characters. For instance, the leading characters are "being shaped, as they approach death, by forces within themselves" (Bailey 7). Explicitly, a man attempts to exercise his enormous power to be important, to discover the truth in facing death, and to suffer from experiencing violent actions. In general,

Mailer's central subject is the relationship between the individual will and a world that attempts to overwhelm and extinguish it. Intimately connected with this spiritual warfare is the subject of power, particularly political power, and the individual's need to resist the encroaching forces of totalitarianism (Miller 67).

What makes Mailer write about megalomania in connection with power is that the "modern man is in danger of losing his dignity, his freedom, and his sense of self before the enormous power of politics and society" (Miller 68). Hence, the "natural role of twentieth-century man is anxiety" (N.D.116) ${ }^{1}$ which is a common feature throughout the novel.

\subsection{Introduction to the Novel of Power}

${ }^{1}$ Mailer, Norman. The Naked and the Dead: With a New Introduction by the Author. Macmillan, 1998. All subsequent
As a famous war novel, The Naked and the Dead is "everywhere acclaimed as the best novel of World War II" (Trilling 151). Undoubtedly, the soldier-army relationship has developed in years, and the soldier in a war novel was "the victim of a force he could neither understand nor control." Trilling says that "the army has become identified with the irrational and destructive authority of society itself"'(152). Trilling also describes this authority as a "death-dealing power" (152). For Maxwell Geismar, the novel emphasizes the individual's associations and struggles within society. Besides, it "attempts to evaluate the whole complex structure of the American Army in war and peace, as a manifestation of contemporary society, as well as a weapon of conquest and destruction" (171). The Naked and the Dead-a milestone in post-war American literature-is, therefore, "a work of enduring power, a power simply incommensurate with the novel's reputation" (Merrill 1).

The Naked and the Dead encompasses multiple genres: political, historical, and documentary. As a novel of ideas, The Naked and the Dead concerns about the war issues generally and about the impact of society and politics on the militant or civilian individuals particularly. Readers, as Glenday sees, are "forced to consider the pathology of power in a military context," hence, "power and its relationship to violence in both the individual and the state leads to Mailer's first dramatization of totalitarianism in American life" (Norman Mailer, 197). Psychologically, the novel illustrates the individual's perception of what is wrong and right within the society as well as a criticism against the individual's loss of faith. As a result, Mailer

[E]quates the army with society and thereby explores the fragmented nature of that society, which has militated against social development, revolutionary or otherwise.

quotations are taken from this edition with the abbreviation $N . D$. with the number(s). 
In so doing, Mailer demonstrates his own loss of faith in the individual's ability to impose himself creatively, perhaps redemptively, on the oppressive condition of the post-war world (Miller 68).

Mailer, who introduces his characters in The Naked and the Dead as being more significant than the military action, deals with all of them symbolically and figuratively rather than literally since he longs for criticizing the individual and society. Similarly, Ihab Hassan refers to the modern self and its suffering from the contemporary life by saying: "spirit is exhausted, civilization is overextended, the individual must move on surfaces or be crushed inward" (12). Such an overpowering statement contains a warning and a cause and effect equation for the exhausted spirit that emerged due to the overextended civilization in all its positive and negative sides. Thus, there is a warning to the modern man: one should develop himself, cope with teething troubles, and be on the tenterhooks in order not to be diminished by the forces of society.

The individual, for Hassan, has a limited power over society in which power exemplifies the inability to make a difference and to possess selfconfidence. Also, the modern man is plagued by impotence and inactivity: two main features ascribed to the sense of alienation. Hassan states:

The individual's sense of his potency, his power to effect change and mold events, seems in a steady decline. It is no great wonder that men choose to withdraw from the public realm of action, though their withdrawal from the world compels them into a fragile or futile relation to themselves (15).

Power, in this case, leads to alienation, anxiety, and frustration in connection with politics. The modern man is not only identified with destructive social forces but also with abusive political ones. The manipulation of power always terminates and controls justice and reason, and it becomes beyond one's will to clarify the main aims. Such manipulation applies to what Foucault asserts: "to sap power, to take power; it is an activity conducted alongside those who struggle for power, and not their illumination from a safe distance" ("Intellectuals and Power," 208).

The title of The Naked and the Dead reflects some substantial meanings. Literally, the connotation of the title refers to the fate of soldiers, being naked and dead, in every war. Lexically, the title comprises three parts: two separate and complementary terms: "the naked" and "the dead" as well as the linking word "and." Such a linking word in the title "implies, not identity, but rather an opposition, between two key terms." "To be naked," as McConnell puts it, "is to be at once terribly frightened, exalted, and intimate with one's own most intensely conscious self" $(66,67)$.

Given that, if there is no arbitrary power defeats one's self, then there will be enough determination in achieving goals. So, Mailer uses the word "naked" several times to mean open, devoid, and vulnerable (Siegel 213). In McConnell's touching words, the second part of the title, "the Dead," shows that man may recognize himself in a time of crisis, and nothing deserves to be upset about:

To be dead is never to have had such a moment, never to have watched the intricate style of your assurances crumble around you and then be forced to recognize that, amid the rubble of that fallen temple of normality, there is to assist in the construction of new and stronger selfhood (67).

The meanings of the novel and its title, in particular, are deeper than one may predict. The non-hypocrite individual is the defeater of a corrupted society only when he is in a state of creating a new way of living and self-confidence. Correspondingly,

In Mailer's world, a man is not only tested and refined by his moments of nakedness, he is also judged by them[...]if the man's past has been one of the tiny evasions, small 
hypocrisies, then the moment will not endure[...] as it should, in the creation or fabrication of a new style for living, a more embracing and heroic style of being in the world (McConnell 68).

The Naked and the Dead describes an American invasion, under the command of General Cummings, of a Japanese island called Anopopei during World War II. The American troops attempt to hold power over the island controlled by the land-based Japanese forces. After embarking there, a reconnaissance, led by Lieutenant Croft and fourteen infantry troops, move to gain information on the enemy's position and number. Symbolically, Anopopei, the fictional setting of the novel, is so significant that Cummings regards it as "a stepping-stone to the apex of political power in the semi-fascistic state he envisions the United States becoming" (Lennon 89). So, the island is a dream about to come true since it is a center for having the power to rule. Like Mailer, the troops perceive it as a terrifying nightmare while Cummings with "the mapmaker's charisma" and Croft with "the trackmaker's undoing" (Leigh, "Spirit of Place," 429) believe in it as life contains "a pattern that [they] can either control or identify with" (Siegel 292).

Structurally, the novel makes up four parts. In part one, "Wave," Mailer describes Lieutenant Croft as a powerful man and shows his violent attitude towards his platoon. Part two, "Argil and Mold," introduces two other characters, General Cummings and Lieutenant Hearn, and their opposing arguments political and intellectual confrontations. "Plant and Phantom" is part three in which Mailer presents another confrontation between Sergeant Croft and Lieutenant Hearn in a physical manner. This part anticipates Hearn's death as well. Lastly, part four, "Wake," sheds light on the end of the novel as well as the supposed victory due to lack of food and ammunition of the Japanese army. Altogether, the four-part structure of the novel plays a vital role in highlighting the issues of power and provides "enormous support to one side of the dilemma of power in the novel." (Leigh, Radical Fictions, 4-5).

\section{Croft's Megalomaniac Behavior}

Early signs of power-hungry and megalomania appear while Croft was playing cards with some troopers late at night. Croft ascertains that he takes over the whole situation, mainly, when a complaining soldier from the rear bunk interrupted them. Expressing his despot and aggressive attitude in front of the others, Croft addressed that trooper, saying: "If you're really looking for something, you can mess with me" (N.D.1). Out of fear, the complained soldier did not answer at all; Croft satisfactorily smiled and sat down. Reactions like these distinguish the victimizer from the victimized and show how boasted, and tyrant Croft is. Also, Croft's smile is a sign of victory and power, whether used positively or negatively. In other words, Croft wishes to impose himself by force in order not to feel offended. In the eyes of the troopers, Croft is an undeniably courageous man whom has been described as "the best platoon sergeant in the Army and the meanest" (N.D.11) and as the one who "loves combat." The narrator carries on saying that there is not "a worse man you could be under or a better one, depending on how you look at it" (N.D.11). Being a combat lover, superior and gloomy, Croft asserts his control, power, pride and, confidence. Croft has confidence that leading men was "a responsibility he craved; he felt powerful and certain at such moments" (N.D.18).

Due to lots of reasons, the platoon men including Hennessey who feel afraid. Watching Hennessey's "white silent face," Croft believes that "Hennessey was frightened and it amused him" (N.D.18). Moreover, the word "amused" refers to the first symptoms of megalomania in Croft's behavior. Confidently, Croft thinks that Hennessey will be killed, this is why Croft keeps "laughing to release the ferment in him"(N.D.11). Croft's response to Hennessey's death is undoubtedly tangible evidence of his megalomaniac conduct 
with which he feels fearless and powerful in absolute contradiction to a trooper's fearful and powerless attitudes. Likewise,

His [Croft's] reaction was similar to the one he had felt at the moment he discovered his wife was unfaithful[....] Hennessey's death had opened to Croft vistas of such omnipotence that he was afraid to consider it directly. All day the fact hovered about his head, tantalizing him with odd dreams and portents of power (N.D.26).

The narrator is so thoughtful that he likens Croft's reaction to Hennessey's death to that of a man who discovers his wife's betrayal. This similarity is, in fact, a reference to unfaithfulness and its relation to demise and power. Furthermore, Mailer ascertains that the Sergeant has a sense of "omnipotence," "odd dreams and portents of power"(N.D.26). Impressively, by "imagining himself in allegiance with fate," according to Diana Trilling's viewpoint, "Croft marshals a will he otherwise lacks, which does indeed alter his fate" (158).

Croft's personality is full of despotic power; Mailer focused on it by using a very skillful technique: Time Machine. Such a technique is intentionally employed to acquaint his readers with his characters, their motives, and their social and psychological whys and wherefores. Besides, Leigh asserts that the "inflexible structure of the book formalizes determinism and establishes restrictive terms for the fictional world Mailer is able to create. The time machine, the most distinctive formal feature of the novel, illustrates this principle"(Radical Fictions, 3). To introduce Croft's terrible experience, for instance, Mailer applies that technique extensively. Leigh continues saying: "Through a series of flashback vignettes, detailed profiles and histories of the characters introduce massive amounts of background material" (Radical Fictions, 3). "SAM CROFT THE HUNTER" is the descriptive name given through one of the flashbacks. The reasons behind this name are a lot:
[Croft] is that way because of the corruption-of-the-society[....] It is because he is a Texan; it is because he has renounced God. He is that kind of man because the only woman he ever loved cheated on him[...] or he was having problems of adjustment (N.D.102).

To sum up the reasons in a few words, Croft is the non-believing and non-adjusted individual within a corrupted society. Croft who is "a mean boy," "just didn't like to have a man interfere with him." Additionally, he could not "stand to have anyone beat him in anythin"" (N.D.102).

After a series of these failed attempts, Croft declares: "I HATE EVERYTHING WHICH IS NOT IN MYSELF" (N.D.107). This inner voice carries a psychological connotation that clarifies his stubborn and dominant personality and leads him to accept future challenges. Although illiterate, Croft is so brave and ambitious that he embraces the war-the ideal sphere of action to him-to satisfy his lust for killing and conquest and to implement his ferocity without fear of retribution.

To understand Croft's personality one has to compare him to Cummings'. Conversely, Croft is "the perfect victim[...]for the General's grim plans" because the former obeyed the orders indirectly. Sociologically speaking, while Cummings is "a self-conscious denier of life," Croft is a "victimized and victimizing destroyer of a life he cannot possess" (McConnell 74). Life adequately represented Cummings' cold feelings toward his wife, but it embodied Croft's being a cuckold. According to Mailer, Cummings' relationship with his wife is a metaphor of sterility, and Croft's is of betrayal. Both of them are metaphors of failure, whether in their present or future situations. Altogether, Cummings and Croft represent a grey vision of the political and social relations by which men are among the visionary "dead" of the title: Cummings has refused his chance for life; Croft has failed to grasp the opportunity (McConnell 75).

\section{Cummings' Authoritative Character}


Similar to Croft's character in using impressive power, General Cummings is another authoritative character whose soldiers look like "a nest of ants wrestling and tugging at a handful of breadcrumbs in a field of grass" (N.D.27). Depicting Cummings' soldiers as "ants" is vivid anticipation of their state of lethargy and deterioration of the spirits. Meeting Lieutenant Robert Hearn for the first time, Cummings demonstrated an unpredictable personality, at least to Hearn. After informing Hearn that he had "powerful enemies," Cummings' self-pity "voice had been disgustingly apparent" (N.D.50) to Hearn who strongly believes it is "quite in contrast to the clear cold sense with which he usually estimated men and events" (N.D.50). Astonished by Cummings' inconsistent attitude, Hearn discerned "quite early that he [Cummings] was a tyrant[...] and a frightful snob" (N.D.50).

Being Cumming's confident aide or intellectual equal, Hearn remembers a description to the General in a newspaper article that "in his manner are combined effectively the force, the tenacity, the staying power of that doughty animal [bulldog] with all the intellect and charm and poise of a college professor or a statesman" (N.D.52). Moreover, this account shows Hearn's sheer desire to understand the real personality of the General or to unravel the contradiction shown before. Introducing Cummings as an intellectual politician and a fascist commander who always thinks of power, Mailer proves that Cummings imposes himself on his soldiers while occupying the island. Cummings' extensive planning to send a patrol to the rear of the Japanese position is "to determine the validity of a new strategic theory [which] is prompted by raw opportunism" (Miller 68). Conversely, this careless strategy that has no connection power leads to the killing of some troops.

Unlike his aide, Hearn, Cummings' "wielding power-for-death involves the exploitation and automatization of the classes he governs" (McConnell 74). After expressing his views on politics, Cummings attempts to corroborate them. Subsequently, he addresses Hearn, saying: 'I've known men who've used filth until it became high art[....] The trick is to make yourself an instrument of your own policy. Whether you like it or not, that's the highest effectiveness man has achieved" (N.D.53). In this respect, Frank D. McConnell claims that "Cummings is an evil man; and his evil consists[...] in the deliberation and callousness with which he takes part in the dance of power and death." In due course, this is a sort of crime against human beings. (73).

Compared to other politicians, Cummings depends heavily upon the political doctrine: "the end justifies the means." Employing such a political principle, Cummings gives proof that he is an interest-seeker and power-hungry. Additionally, through expounding theories on defense, Cummings seizes the opportunity to discuss with Hearn:

If you're holding a gun and you shoot a defenseless man, then you're a poor creature, a dastardly person[....] The fact that you're holding the gun and the other man is not is no accident. It's a product of everything you've achieved; it assumes that if[...]you're aware enough, you have the gun when you need it (N.D.54).

Cummings considers ultimate power as having a gun and authority. The person who uses these tools irrationally will misuse them or oppress others with them.

Politically, Cummings, a totalitarian, was rebuking Hearn for being a liberal, Cummings addresses Hearn: the trouble is: "liberal' means good and 'reactionary' means evil" (N.D.54). Likewise, Cummings "hopes for a war to outlast the war for an era of totalitarian power of which World War II would be only the prelude" (McConnell 74). Symbolically speaking, Cummings signifies the fundamental connection between the political theme and the social one, not to mention the personal and psychological aspects. Moreover, Randall H. Waldron states that “Cummings' function as a symbolic character has 
crucial implications for the central theme of the novel: that the machine is capable of extending its domination to the most fundamental levels of man's existence, of becoming a threat to his very nature and his humanity" (276). Being a totalitarian means that one has a force of a machine that normally defeats the human force. The power used in this case is a "'disciplinary power': a form of power focused on the control and discipline of bodies and exercised fundamentally 'by means of surveillance.' Besides, "the techniques of disciplinary power[...]had long been in existence in monasteries and armies[...]these specific techniques dispersed and pervaded social life [and] focused on the body as the 'object and target of power"' (Bennett 38-39).

The military organization has forced General Cummings to give up human relationships completely; it has also forced him to keep dominating by using political ideas and through humiliating his aide to control him by force or maybe by magnetism. Obliged to stay in Cummings' tent, Hearn finds himself controlled by the former's magnetic power; "he couldn't escape the peculiar magnetism of the General, a magnetism derived from all the connotations of the General's power" (N.D.54-55). The General's personality, knowledge, ambition, and the art of persuasion show his power as absolute, arbitrary, and commanding.

In a political argument between Cummings and Hearn, the former longed to expose his ideas on liberalism and on winning this current war, stating that the "root of all the liberals' ineffectiveness comes right sprang out of the desperate suspension in which they have to hold their minds[.... The type of thing that preoccupied me was what makes a nation fight well" (N.D.114). Similarly, Cummings deliberately gives an example of his superior thinking as totalitarian in comparison with that of Hearn, being a desperate liberal. Cummings is keen to show Hearn's misconception of his beliefs and invalidity of his ideas which are wrong at least to Cummings. Subsequently, he begins to theorize: "If you're fighting in defense of your soil, then perhaps you're a little more effective[.... After a couple of years of war, there are only two considerations that make a good army: a superior material force and a poor standard of living" (N.D.114). The General's view in this quotation wholly opposed to the ideology of the liberals. To Cummings' mind, as Leigh believes, "the American model of [an] open society is decadent; the individual freedoms it rests upon are excessive, dysfunctional and harmful to the idea of [the] system"(Radical Fictions, 8-9).

Being an American and an authoritative person, Cummings believes that he has many potentials that allow him to control others and occupy their countries. Trying to convince Hearn, Cummings states, "We have the highest standard of living in the world and[...]the worst individual fighting soldiers of any big power" (N.D.115). To affirm his ideas, Cummings keeps repeating the same words: "Break them down. Every time an enlisted man sees an officer get an extra privilege, it breaks him down a little more" (N.D.115). For Hearn, the "big power" means breaking others down; ultimately this will increase the others' hatred. Cummings is familiar with the idea of being hated. However, he wishes others to fear and avoid him. Cummings, who belongs to the army, an organization that imposes its absolute power and control by force, horror, fear, injustice, imprisonment and superiority, commands by the power of position rather than any other aspects. To be a part of the army means that Cummings rejects his humanity and turns into a machine or even a robot devoid of senses and feelings. Through his imposing and continuous conversation with Hearn, Cummings warns Hearn and conveys some messages to readers as well. To sum up the concept of power, Cummings concedes:

Every time there's what you call an Army injustice, the enlisted man involved is confirmed a little more in the idea of his own inferiority[....] The methods used [in prison] will be brutal, and it's going to cause a stink eventually, but it happens to be necessary[....] [T]o make an Army work 
you have to have every man in it fitted into a fear ladder. Men in prison camps, deserters, or men in replacement camps are in the backwaters of the Army, and the discipline has to be proportionately more powerful. The Army functions best when you're frightened of the man above you and contemptuous of your subordinates (N.D.115).

It is believed that the reasons behind joining the army for Cummings and even for Croft are seeking power related to authority. Likewise, Foucault states that "prison is the only place where power is manifested in its naked state, in its most extreme form[....] What is fascinating about prisons is that, for once, power doesn't hide or mask itself; it reveals itself as tyranny pursued into the tiniest details"("Intellectuals and Power," 210). As a militant, Cummings defines the person with power as the one who does not fear his superiors and humiliates his inferiors who hate him in return. The balance of power, in Cummings' belief, will disappear as soon as one loses his office, authority, and reliability. Also, being powerful means that you are a military man, capitalist, charismatic person, and American, as Cummings strongly believes.

The cigarette end incident, between Cummings and Hearn, illustrates other kinds of fear and power of Cummings appear. While talking to Cummings, Hearn throws a cigarette end on Cumming's tent floor. For Cummings, Hearn's action is an attack, and an explicit denial of his authority; the incident "was a symbol of the independence of his troops, their resistance to him. The fear, the respect his soldiers held for him now was a rational one, an admission of his power to punish them, and that was not enough" (N.D.212). Realizing what is happening, Hearn must defy the whole matter openly and heartlessly, saying: "The longer you tarried with resistance, the greater it became. It had to be destroyed" (N.D.212).

Cummings' talk explains the title of the novel in a more comprehensive way. Cummings becomes the mouthpiece of Mailer in explaining the inherent meaning of that title in connection to power and history. Cummings addresses Hearn, declaring:

Your men of power in America[...]are becoming conscious of their real aims for the first time in our history[....] After the war, our foreign policy is going to be far more naked, far less hypocritical than it has ever been. We're no longer going to cover our eyes with our left hand while our right is extending an imperialist paw (N.D.214).

As a powerful country politically, economically, and militarily, America to Cummings is the country in which only powerful men can live, achieve their goals, and control others.

Morally, Cummings proceeds his theories on power and how to achieve it. By impressing Hearn who is so eager to be a powerful man, Cummings claims, "the only morality of the future is a power morality, and a man who cannot find his adjustment to it is doomed." In Cummings' words, "there's one thing about power. It can flow only from the top down. When there are little surges of resistance at the middle levels, it merely calls for more power to be directed downward, to burn it out" (N.D.215). Additionally, once you are a powerful man, there is also a powerless one whose humiliation and victimization directed by the latter.

The long conversation between Cummings and Hearn, two different forces: totalitarianism and liberalism, reaches its peak with the cigarette end thrown by Cummings to belittle Hearn who has thrown a cigarette end at the former's tent floor earlier. Cummings addresses Hearn: "If I were to throw this down on the floor, would you pick it up?" Hearn considers the orders "a bit steep." Cummings replies: "It's tremendously steep, it has to be" (N.D.216). At the zenith of Cummings' pride in this incident, power is an absolute one. He proclaims:

There was the old myth of divine intervention. You blasphemed, and a lightning bolt struck you. That was a little steep too. If punishment is at all 2547 
proportionate to the offense, then power becomes water. The only way you generate the proper attitude of awe and obedience is through immense and disproportionate power (N.D.216).

Forced to pick it up, Hearn unwillingly says: "I resent this. It's an unfair proposition"[.... "A series of emotions, subtle and conflicting, flowed behind the surface of his face[....] Cummings forced himself to face the hatred in Hearn's eyes. He was feeling an immense relief" (N.D.216). Felt humiliated, Hearn asks the General to transfer him into another division. The entire incident, as Leigh points out, refers to what Hearn misjudges which is "the degree to which the symbol might accumulate meaning in an imagination keyed to the minutest nuances and calibrations of power"'(Radical Fictions, 17). Moreover, Cummings' fervent general understanding makes inexplicable "connections between Hearn, the cigarette, the troops in his command and the Japanese enemy" (Leigh, Radical Fictions, 17-18).

At last, the cigarette, as a powerful symbol during the conversations between Cummings and Hearn, implies masculinity, greatness, luxury, and above all power. The cigarette is used as a means of control to Cummings and humiliation to Hearn as well. The cigarette for Cummings comes to "threaten the army as a preview of the future, the bureaucratic pattern of the totalitarian dream." Similarly, the narrator states: "Hearn was an embodiment of the one mistake, the one indulgence he had ever permitted himself, and it had been intolerable to be with him since then" ( N.D.273). Similarly, Foucault believes that "each struggle develops around a particular source of power." He goes on giving reasons "to force the institutionalized networks of information to listen, to produce names, to point the finger of accusation, to find targets[....] [This] is the first step in the reversal of power and the initiation of new struggles against existing forms of power" ("Intellectuals and Power," 214).

\section{Hearn's Ineffective Power}

Standing between Cummings and Croft, though never meet, lieutenant Hearn is in a central position in the novel dramatically as well as thematically. Hearn's humiliation by Cummings sends him to Croft's platoon where Croft plots his death for many reasons: jealousy, control, and power. Hearn's death at the hand of the Japanese before Croft's eyes proves the latter's revenge. Ironically, Hearn wishes to make "the world in his own image and impose his will upon it" (Hassan 147). Nevertheless, he falls victim to the most powerful intrigues played by an oppressive man, namely Croft. Besides, "Hearn shows a secret affinity with the Faustian impulse of the two men (Cummings and Croft) he must oppose." "Not a phony but a Faust"(N.D.385).

Although Hearn makes a great balance in the entire novel, he is also a victim of his desire for the considerable power on the one hand and to the authoritative men on the other. Hearn "is an ideal figure to become the unifying consciousness, the central moral voice of The Naked and the Dead" (McConnell 75). As a tragic hero, Hearn has a passive role, and he keeps watching what is happening around. In this connection, Mailer's heroes (Hearn is one of them) maximize the effort involved to "understand a complex situation, all the while keying themselves to the point of urgency, the critical point of understanding where the action is unremittingly forced upon them" (McConnell 75). Indeed, Hearn always stands for the watcher or the spectator who tries his best to comprehend Cummings' theories and Croft's experiences. Being an urban hero, Hearn relates to the downtown and vague society in which he attempts to grasp its complex mixture, but he finds a difficulty in so doing. In this respect,

To the Mailer hero, the Mailer sensibility, society in its everyday appearance is a sham, a trap hiding beneath it deep and dark conspiracies, games of power and death which are subtle perils to the soul. The Mailer hero, then, characteristically enters upon a process of examination, investigation, and discovery whose final 
illumination, ideally, will force him into just such a shattering confrontation with the existential void (McConnell 75-76).

In other words, appearances are always deceptive. Society cares for those who are commanding in different perspectives, and it ignores the ineffective, though full of morality. So the hero who is in the process of discovery all the novel has a double role thematically and technically. Hearn also embodies the modern hero who is different from any other hero. This modern hero, surrounded by lots of obstacles, cannot overcome difficulties easily. Cleverly, Mailer imposes a hero, or rather, an anti-hero to emphasize his notion concerning the modern man in contemporary society. Critics believe that Mailer wants to show his readers the victimized and the victimizer and the battle between the human versus nonhuman:

In [the] modern novel, [the] man seems to overcome the contradictions of his experience, its destructive or demonic element, by assuming the role of [the] antihero, the rebel-victim. The rebel denies without saying No to life; the victim succumbs without saying Yes to oppression. Both acts are, in a sense, identical: they affirm the human against the nonhuman (Hassan 31).

The Naked and The Dead introduces another image of man as being corrupted, hesitant, confused to the point of helplessness. These qualities are particularly applicable to Hearn, a liberal intellectual who is in the middle of the hammer and the anvil of great antagonistic forces. This situation means that Hearn plays a vital role in linking both of the power struggles, and he is the defeated one in each. Hearn not only bridges the gap between the two main characters, Cummings and Croft but also between the soldiers and commanders. Hearn signifies the liberal voice and the moral side in his society; he is a somewhat mysterious and empty character as well. Symbolically, Hearn who is presented as weak and ineffective stands for liberalism to Mailer. Likewise,

This surprising deficiency in Hearn is surely intentional, as Mailer introduces an intelligent and sometimes outspoken man only to emphasize how ineffective he is. Resented both by the commanders and by the soldiers, he is eventually killed for no purpose; such is the fate of liberalism in Mailer's universe (Miller 69).

There are certain similarities between Hearn and the two victimizers: Cummings and Croft. Hearn showed the same impulses that provoked Cummings and Croft: power, control, and appearances. Since power appeals to Hearn, he is fascinated by Cummings, who has the ability "to extend his thoughts into immediate and effective action" (N.D.49). Moreover, Cummings addressed Hearn, saying: "Always there was the power that leaped at you, invited you" (N.D.235). Whereas Hearn hates his position in respect to Cummings, his hatred blends with his desire to be in the vein of Cummings: "he had acquiesced in the dog-role, had even had the dog's dream, carefully submerged, of someday equaling the master" (N.D.208). Considering that "he was basically like Cummings," Hearn even feared "when he searched himself," that "he was just another Croft"(N.D.262; $385)$.

As a winner, Cummings proudly mentioned that "Chess is inexhaustible" and it is close to life. "What a concentration of life it is really," he wonders (N.D.117). Perceiving no link between chess and life, Hearn alleged that he disagreed with Cummings' metaphorical speech, and as a result, resisted both Cummings and Croft politically. Hearn's political views are questionable for many critics who generally believe that Hearn is a liberal. However, Leigh (1990) and Merrill (1992) recognize Hearn as a radical liberal and an aristocrat respectively. Although he allegedly represents all of them, Hearn, as Glenday thinks, is a victim due to his liberalism: 
Hearn's liberalism is often seen to be a soft target, easily collapsing in the face of Cummings's theoretical rigour, and proving no match for Croft's manic singlemindedness. Hearn [has] a force that can 'counteract the personal and political excesses of the other two major characters,' one who 'provides a positive point of resistance to the fascism of Cummings and Croft' (Norman Mailer, 209).

Through Hearn, Mailer denotes that "power is fundamentally structuralistic and expressive of domination, coercion, and manipulation" (Leigh, Radical Fictions, 15). Hearn is attached to the belief that "the essential nature of power is repressive and that enlightenment is emancipation from power relations" (Leigh, Radical Fictions, 15). Hence, to achieve freedom, Hearn has to overcome the repression of power represented by the two oppressors, society and politics. Hearn's role is to stand up for the repressive power employed by Cummings and Croft. Similarly, Hearn reflects Michel Foucault's definition of power in which he states: "Power is essentially that which represses. Power represses nature, the instincts, a class, individuals"( "Intellectuals and Power," 90).

In The Naked and the Dead, the conflict revolves around the main three characters: Cummings, Croft, and Hearn who, on the one hand, fought an ideological war against one another and a real war against the Japanese on the other hand. In this respect, the central conflict in the novel is between "the mechanistic forces of "the system"" best personified by General Cummings and Sergeant Croft. "Against these, is ranged the 'confused humanism' of Lieutenant Hearn." This conflict shows the machine as a victor, and human as defeated and murdered by the two oppressors indirectly.

Cummings and Croft are defeated too, and "their individual will to conquer undermined by the absurdities of chance (Croft and his platoon run in panic from a swarm of hornets when Croft kicks over their nest accidentally[....] Cummings's plan to outflank the Toyaku line is thwarted by Dalleson's success, which is achieved by accident rather than by design)" (Glenday, "The Hot Breath," 202). Together Cummings and Croft epitomize men of middle-class background, their self-interest and over-ambition make them victimizers to anyone else under their command. Sarcastically, blaming their followers for shortsighted opinions, Cummings and Croft shared ultimate power and domination from different perspectives.

One of the most shocking events that show Croft's arrogant cold-blooded behavior is that of the Japanese prisoner. Croft and his recon caught one of the Japs as a prisoner, and Croft's reaction was so cold and provocative toward that prisoner. Croft, who had the intention of killing that prisoner, sought after giving comfort and safety indications though. After giving him hope in life, Croft killed the Japanese soldier, because he sees war as "a nice measure of satisfaction of an unquenchable lust for conquest and blood" (Trilling 152). The entire action is an obvious reference to Croft's commanding and megalomaniac attitude which is full of "blank" feelings: "The smile on the dead man's face amused him, and a trivial rill of laughter emitted from his lips" (N.D.129). Mailer illustrates how Croft's reaction towards power and weakness is: "He hated weakness, and loved practically nothing. There was a crude unformed vision in his soul, but he was rarely conscious of it" (Miller 70). The narrator's words best summarize Croft's personality and opinion about death as a kind of justice:

Croft always saw order in death. Whenever a man in the platoon or company had been killed he would feel a grim and quiet satisfaction as though the death was inevitably just[....] Croft did not believe that the longer he was in combat the poorer his chances became. Croft believed a man was destined to be killed or not killed, and automatically he had always considered himself exempt (N.D.294) 
When someone is killed, Croft feels satisfied and believes that he is superior to them for not being murdered. Croft's platoon's weakness leads to their death as he proclaims. Power, for Croft, means experience, survival, and control with which he becomes more compelling than his platoon.

Furthermore, feeling immortal and ambitious, Croft, who must climb Mount Anaka, the highest peak on the island, has confidence in himself to achieve his goals. Thus, critics likened Croft to Faust who scarifies everything to attain his ambition:

Faust here assumes the shape of a Texan hunter - the criminal. [Croft] murders a Japanese prisoner, after giving him a cigarette, simply for the sinister excitement of the thing. Croft's sense of his omnipotence[...]is primitive, almost feral. The mountain comes to represent for him everything he must know and conquer, the way to his own immortality (Hassan 146).

In the event of killing a bird, a turning point in the novel, and Croft's life, Mailer ironically showed power in the powerless bird rather than the powerful Sergeant. While Croft was so busy working on a stretcher, Roth, one of the platoon soldiers, found a tiny bird with a crippled wing and played with it so gently. This bird was not only a source of attraction to the rest of the platoon. Symbolically, they viewed it as part of solace, pleasure, and compensation for their faraway families. Nonetheless, Croft held it as a challenge for his power:

Roth was completely absorbed in the bird[....] Roth had fallen in love with the bird immediately. It was lovely[....] He felt exactly the same joy he knew when his child had plucked at the hairs on his chest[....] He could not have picked a worse time to antagonize Croft. And deep within him, his rage was alive again, flaring. Everything was wrong, and Roth played with a bird, while nearly half the platoon stood about watching (N.D.351).
Angrily, Croft asked Roth to hand him in the tiny bird. After catching the bird, he could feel "the bird's heart beating like a pulse against his palm. Its tiny eyes darted about frantically, and Croft's anger worked into his fingertips. It would be the simplest thing to crush it in his hand" (N.D.351). To describe the entire scene, Mailer provides two images: powerful water thrushes through the cracks of rocks and a thin card on edge about to fall. Symbolically, these two images focus on the confrontation between the powerful and the powerless and its concerns. While the others were watching, "[s]trange impulses pressed through his nerves, along his muscles, like water forcing itself through fissures in a rock mass[...] and the impulse, confused and powerful, shimmered in his brain like a card on edge about to fall'(N.D.351). After Croft had killed the bird, the soldiers' quick reaction was shocking: the entire platoon stood up to Croft for the first time, even many of them wondered furiously concerning his malicious and cruel action. Hence, this accident and its consequences uphold that Croft is ineffective and as if he were humiliated owing to his pompous power: a tiny bird beats an oppressive military Sergeant!

The other repercussions resulted from the above accident are Croft's relationship which he strikes up with Red Valsen and Hearn. For instance, in the case of Valsen, Croft increases the hostility by his action through which Valsen "knew without ever admitting it that he was afraid of Croft." However, he questioned Croft angrily: "What's the matter, Croft, you throwing orders around to save [yourself]?" Being shocked, Croft retorted: "I've had enough, Red." "You bit off a little too much this time" (N.D.352). Knowing of the incident, Hearn forced Croft to apologize to Red. Croft unwillingly said:

If Croft had been holding a rifle in his hand, he might have shot Hearn at this instant. That would have been automatic[.... $\mathrm{He}$ knew he had to comply. If he didn't, the platoon would fall apart. For two years he had molded it, for two years his discipline had not relaxed, and one breach like this 
might destroy everything he had done[....] He felt as if his flesh were crawling with vermin" (N.D.353).

The last image of vermin, a kind of worms or animals that destroy crops or the human body by spreading diseases, is proof of Croft's loss of power or control from different perspectives. It is also a sign of his failure in his next mission which is climbing Mount Anaka.

Croft's power and ambition mainly appear when he decided and insisted on climbing "over the mountain," Anaka (N.D.293). Croft exploited men and nature to fulfill his ambition, for he sees "evil as a vital force" which provides him with "energy and a decisive manner that the weaker, idealistic characters lack" (Miller 70). Croft's powerful personality is shown in his behavior and in his ambition through which he "seeks a channel in which to funnel his powerful drives" (Miller 70).

Croft's resilient aspiration to climb the mountain further illustrated that he was tremendously exhausted and ignored himself and the others to proceed. Despite being so decisive and steadfast, Croft shows that he is reckless too; to him, it was necessary not to retreat:

Croft[...]wanted to quit too, and each time a break ended he fought a quick battle with himself, exposed himself to all the temptations of rest, and then continued. He moved on because somewhere at the base of his mind was the directive that climbing this mountain was necessary[....] He could have turned back no more easily than he could have killed himself (N.D.438).

The power of nature and geographical places play a vital role in overcoming the arrogant and violent Croft whose power is defeated by the mountain which is a symbol of charm. As an environmental theorist puts it: "Certain aspects of nature defy every human control: these are the mountains, deserts, and seas. They constitute[...]permanent fixtures in [a] man's world. To these recalcitrant aspects of nature man has tended to respond emotionally" (qtd in Leigh, Radical Fictions, 28).
Two opponents had been face-to-face: Croft and Red who denoted a specific category of power: the power of dictators and that of the rebellious. As a consequence of his dominant power, Croft, expectantly, threatened Red by shooting him. Still, after rebelling against Croft's intimidation, Red hopes that the others support him; unfortunately, no one cares, or preferably they are scared. Hence, Croft turned and gazed at the others, threatening and asking: "Who wants to get lined up with Red?" "Awright, Red, go get your pack" "Ah'm gonna shoot ya in about three-four seconds" (N.D.463). Described as standing feet away and aiming his gun towards his soldier, Croft has the intention to shoot Red who "found himself watching the expression on Croft's face" (N.D.463). Consequently, after watching Croft's finger on the trigger, Red surrendered suddenly. Croft beats Red who grumbled half-heartedly.

While he was retreating from climbing, Croft was staring at the mountain, the utmost perplexing barrier he had ever faced. Anxious, powerless, and insecure, Croft alleged that he was climbing it alone. The narrator brilliantly described Croft's feelings while losing his power, control, and the life:

A stream of wordless impulses beat in his throat and he had again the familiar and inexplicable tension the mountain always furnished him. To climb that, he had failed, and it hurt him vitally. His frustration was loose again. He would never have another opportunity to climb it. And yet he was wondering if he could have succeeded. Once more he was feeling the anxiety and terror the mountain had roused on the rock stairway[.... The empty hills would have eroded any man's courage" (N.D.472).

Not only had Croft lost the mount and himself but also the entire life. Symbolically, climbing the mount resembles going up a stairway full of obstacles on its steps, and half the way up, one faces many skirmishes that stop him from 
ascending. The all-inclusive situation is a palpable suggestion to struggling against the odds of life.

It seems that Croft and Cummings are losing their power in a way or another specifically near the end of the novel. A closer examination of Cummings, lying in his tent, contemplating his situation, reveals his miserable condition of losing the battle. The narrator gives an overall impression concerning the full scene by saying:

The power, the intensity of the urges within himself, inexpressible, balked, seemed to course through his limbs, beating in senseless fury against the confines of his body. There was everything he wanted to control, everything, and he could not direct even six thousand men. Even a single man had been able to balk him (N.D.200).

Cummings felt that he was losing power for scores of reasons: fear, failure, and despair. Indeed, "he was afraid; failure now would be fatal." "It was acutely difficult now to conceal his annoyance with the most insignificant details, and it was affecting everything about him[...] he felt powerless to alter it [the division]" (N.D.200). Cummings, who thinks that the whole island, Anapopei, is an ocarina on which he plays his tune, becomes desperate suddenly owing to his lazy troops. The map of this island is skillfully and intentionally used by Mailer to make "the first of many gestures towards the great reality[...] it is, in fact, a crucial part of the novel's design, functioning both as a controlling metaphor of the book and a guide to the process of reading it" ("Leigh, Spirit of Place," 427).

As a novel of symbols, Mailer's The Naked and the Dead is summed up symbolically by Diana Trilling in her "The Radical Moralism of Norman Mailer" as follows:

In Mailer's political scheme he [Cummings] is, simply, fascism, and Croft is his eager though unconscious collaborator. The suffering men in Croft's platoon, who endure unspeakable torments as they struggle through swamp and jungle on Cummings' order and who, without a voice in their fate[...] are the masses of mankind who lack the individual or collective will to resist being propelled to annihilation (Trilling 153).

According to Sandy Cohen, Mailer analyzed the wide-ranging, complex, intermingled, and changing psychological, social, and, precisely, political forces he observed around him. These forces threatened the end of individual autonomy, dignity as well as human compassion. Poorly affected by the whole situation, Mailer becomes so concerned about the effect of politics and society on the individual. Throughout the novel, the immediate impact of political and social powers on the essential characters' destiny has become clear (10).

Michel Foucault shows, wonders about and criticizes "the effects of power as repression," stating:

$[\mathrm{P}]$ ower is taken above all as carrying the force of a prohibition. Now I believe that this is a wholly negative, narrow, skeletal conception of power, one which has been curiously widespread. If power were never anything but repressive if it never did anything but to say no, do you really think one would be brought to obey it[...]? It needs to be considered as a productive network which runs through the whole social body, much more than as a negative instance whose function is repression (Knowledge/Power, 119).

\section{Conclusion}

The predominant theme in Mailer's The Naked and the Dead is power as tackled from many perspectives especially the psychological and the sociopolitical ones. To conclude, the central conflict in The Naked and the Dead is between the mechanistic forces and the will to individual integrity. On the one hand, there are Commanding General Cummings, the dazzling and unsympathetic fascist whose power and control are matchless throughout the novel except for near the ending, and the iron-handed and callous Sergeant 
Croft who has almost the same characteristics as Cummings. Both of them personify the machine which has no senses and destroys everything. In contrast to them the confused and deceived Lieutenant Hearn and the rebellious and brave Private Red Valsen attempt to maintain their dignity and identity from the very beginning until the end of the novel. The machine as expected wins at the human fails, however, at the novel's end, Hearn is dead or sent by the machine to be dead and Valsen is defeated and humiliated. Likewise, Croft is beaten and demeaned by nature, and Cummings' ambitions thwarted by not winning the war by himself against his enemy. Ironically, Cummings, who believes himself to be superhuman, is disappointed to achieve his aims and goals by chance. Cummings' defeat came in the shape of Major Dalleson, and by his troops' resistance to any change with enraging inaction.

Mailer established chance and nature as two elements of naturalism which strengthen the relationship between characters on the one hand and environment and worldview on the other. Cummings treated Hearn tyrannically and intellectually; while Croft treated Valsen aggressively and sadistically. Cummings and Croft behaved as prototype fascists, villains, oppressors, and victimizers; Hearn and Valsen acted as archetypal liberals, antiheroes, oppressed, and victims. The four significant figures suffer an extraordinarily similar fate: each good character is defeated and beaten by his totalitarian opponent and oppressor.

Power, related to the person's background and status, is the goal of those who are considered powerless, impotent, and useless specifically if it is misused. Power, compared to a machine with no senses or emotions, crushes everyone ahead including the person who seeks power by position, institution, or even in mind. As one of life's tendencies, desires as well as motives, power is essential to be employed against oppression, victimization, and injustice, not the contrary. Throughout the novel, most of the events and incidents end with the victory of the weak in a way or another. In other words, powerless forces defeat the compelling characters. Thus, this issue is an explicit indication of the failure of Cummings' and Croft's intentions which ultimately indicate the failure of the machine and its negative impact on man and nature. Also, the delivered message is a justification for modern man's refusal to be dehumanized by the forces of mechanized society. On the other hand, Hearn's death and Valsen's humiliation mean the defeat of man by the machine.

almost every character is victimized due to many reasons: war, impotence, bullying, missing opportunities, alienation, and megalomania, and are existentially naked and imaginatively dead or instead they are physically alive and spiritually dead. Mailer's last message is that the individual has to either yield to oppressive forces or to attempt to maintain some spiritual independence and dignity.

\section{Works Cited}

[1] Bailey, Jennifer. Norman Mailer QuickChange Artist. Springer, 1979.

[2] Bennett, Tony. Museums, Power, Knowledge: Selected Essays. Routledge, 2017.

[3] Cohen, Sandy. Norman Mailer's Novels. Amsterdam: Editions Rodopi N. V., 1979.

[4] Crossman, Ashley. "Power Definitions and Examples in Sociology." ThoughtCo, Jun. 22 , 2018, thoughtco.com/power-p23026460 .

[5] Foucault, Michel, and Gilles Deleuze. "Intellectuals and Power." Language, Counter-memory, Practice (1977): 205217.

[6] Power/Knowledge: Selected Interviews and Other Writings, 1972-1977. New York: Pantheon, 1980.

[7] Geismar, Maxwell David. American Moderns, from Rebellion to Conformity. Hill and Wang, 1958.

[8] Gordon, Andrew. An American Dreamer: A Psychoanalytic Study of the Fiction of 
Norman Mailer. Fairleigh Dickinson Univ Press, 1980.

[9] Glenday, Michael K. Norman Mailer. London: Macmillan, 1995.

[10] "The Hot Breath of the Future: The Naked and the Dead," in Bloom, Harold, ed. Norman Mailer. Infobase Publishing, 2003.

[11] Hassan, Ihab. Radical Innocence: Studies in the Contemporary American Novel. 1963.

[12] Hornby, A S, et al. The Advanced Learner's Dictionary of Current English. $8^{\text {th }}$ ed. London: Oxford University Press, 2015.

[13] Leigh, Nigel. Radical Fictions and the Novels of Norman Mailer. Springer, 1990.

[14] "Spirit of Place in Mailer's The Naked and the Dead." Journal of American Studies 21.3 (1987): 426-429.

[15] Lennon, J. Michael. Norman Mailer: A Double Life. Simon and Schuster, 2014.

[16] Mailer, Norman. The Naked and the Dead: With a New Introduction by the Author. Macmillan, 1998.

[17] Merrill, Robert. Norman Mailer Revisited. Twayne Publishers, 1992.

[18] Miller, Gabriel. "A Small Trumpet of Defiance: Politics and the Buried Life in Norman Mailer's Early Fiction," in Bloom, Harold, ed. Norman Mailer. Infobase Publishing, 2003.

[19] McConnell, Frank D. Four Postwar American Novelists: Bellow, Mailer, Barth, and Pynchon. Chicago: University of Chicago Press, 1977.

[20] Siegel, Paul N. "The Malign Deity of The Naked and the Dead." Twentieth Century Literature 20.4 (1974): 291-297.

[21] Swedberg, Richard, and Ola Agevall. The Max Weber Dictionary: Key Words And Central Concepts. Stanford University Press, 2016.

[22] Trilling, Diana. "The Radical Moralism of Norman Mailer." The Creative Present (New York, 1963): 157.
[23] Waldron, Randall H. "The Naked, the Dead, and the Machine: A New Look at Norman Mailer's First Novel." Publications of the Modern Language Association of America (1972): 271- 277. 